\title{
Sobre a contabilidade da revista
}

\author{
Harley E. A. Bicas
}

Se tivesse que citar uma condição significativa e marcante destes dez anos em que tive a honra de servir aos Arquivos Brasileiros de Oftalmologia como seu Editor-Chefe, mencionaria que, além da contribuição fundamental e indispensável dos colaboradores da revista - Co-Editores, Editores Associados, Conselheiros Editoriais (funcionais e "ad hoc"), pessoal de apoio logístico, sem os quais nada poderia ter sido feito - o que se sobressaiu foi a sensação de liberdade de ação... De fato, além da independência editorial, cuja gerência subordinouse (confiada pelo Regimento do C.B.O.), a um órgão relativamente independente de políticas institucionais, o Conselho Administrativo dos Arquivos Brasileiros de Oftalmologia, chamou-me a atenção o fato de que nunca, e repito, nunca houve sequer uma única vez em que fui abordado para "diminuir custos", "restringir o volume das publicações", "equilibrar orçamentos", ou coisas que tais. Numa cultura em que o lucro é o grão-senhor das corporações e numa sociedade em que as preocupações sobre economia e finanças subjugam mentes e corpos, é deveras curioso que esse assunto jamais viesse a ser discutido. Aliás, e ao contrário, convém registrar que oportunidades de maiores gastos com a publicação da revista chegaram a ser oferecidas (por exemplo, a de publicação integral dos artigos tanto em português quanto em inglês).

É verdade que todo o fluxo de caixa da revista, recebimentos e despesas, cabe à Tesouraria do C.B.O. e é bem compreensível que possa haver uma "liberdade vigiada", deixada de se transformar em controle estrito por não ocorrerem abusos com a "carta branca" então usufruída (ainda que não formalmente outorgada). De qualquer modo - e muito longe do que se possa pensar como irresponsabilidade de direção - o que permeou esse elegantíssimo silêncio por parte das Diretorias do C.B.O. sempre foi uma atitude de respeito e confiança que, sobretudo, dignifica a revista. Assim, apesar de toda a subordinação econômica ao C.B.O., as publicações de nossa revista nunca foram vitimadas pela cultura de que quem financia impõe seus mandos.
E o que ganha o C.B.O. ao sustentar sua revista científica? De um ponto de vista ainda puramente financeiro, nada. Aliás, o balanço contábil da revista é negativo. Claro, por outro lado, que pela distribuição gratuita da revista aos seus membros associados, poder-se-ia supor que o C.B.O. deixe embutido, na cobrança das respectivas anuidades, uma parte de seus custos. E uma vez que esses valores fossem computados, talvez se chegasse a reverter o resultado da contabilização, desse modo transformado em positivo. Por outro lado, se os exemplares não fossem assim distribuídos é bem possível que as assinaturas da revista caíssem muito e aí, sim, o C.B.O. teria desembolsos para manter a continuidade da publicação (determinada como uma das finalidades estatutárias da instituição). Ou seja, por uma análise, ou por outra, a sustentação da revista caberia aos membros associados do C.B.O. e o resultado, portanto, seria praticamente idêntico.

Mas é inegável, e acima de qualquer eventual polêmica, a conveniência da existência de nossa revista para a Oftalmologia brasileira e, por consequência, para o Conselho Brasileiro de Oftalmologia. Desse modo, mesmo que se lhe admita um valor contábil negativo (o que, como visto, pode ser objeto de discussão, dada a relatividade como a distribuição dos exemplares é feita aos associados), essa figura não pode ser tomada como "despesa", mas sim como investimento. Uma boa analogia, parece-me, é a dos gastos realizados com os estudos de um filho, com os de seus aperfeiçoamentos, com suas aquisições de capacitações, com suas potenciações de "ganhos" futuros: Ainda que saiam do bolso e custem, isso são despesas ou investimentos?

Entretanto, mesmo como investimento, a necessária visão com que se deve contemplar os Arquivos Brasileiros de Oftalmologia, a carinhosa atitude e comportamento das Diretorias que dirigem a Oftalmologia brasileira e seus destinos para com a revista honraram e honram sua administração.

Minhas reverências e agradecimentos às gestões do C.B.O. que tão bem compreenderam o valor desse gestual de apoio. Mais do que confiança em administração, assim se outorga um prêmio de valor inestimável. Obrigado! 